ON THE RECORD

'We ran aground on a coral reef we were trying to protect."

Greenpeace says somy after its boat, Rainbow Warrior II, hits an ecologically fragile reef in the Philippines.

\section{"If find it inconceivable} that this paper is not well known."

Comell physicist Neil Ashcroft is surprised to discover an obscure 1922 paper on superconductivity by Albert Einstein. A translation of the paper is now on the arXivphysics preprint server.

Sources: CNSNews.com, PhysicsWeb

\section{SCORECARD}

Memorials
An art company basedin
Japanis offering a fresh twist forgardens of remembrance. Itplans tomake 'living tombstones' by generating trees whose every cell contains the DNA from a deceased loved one.

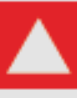
Child prodigies An eight-year-old boy who dreams of building flying cars andjoining the European particle-physics laboratory, CERN, has become the youngest pupil to enrol at a South Koreanuniversity.



Jet lag

Researchers in Chicago believe they have come up with a potent method for resetting travellers' body clocks. They say that a combination of brightlight and melatonin has a much stronger effect than either elementon its own.

\section{NUMBER CRUNCH}

A survey by the American Association for the Advancement of Science reports that $40 \%$ of its members have had 'difficulties' acquiring patented technologies to use in their work. Among those who hadproblems:

$\mathbf{5 8} \%$ said that theirwork was delayed by the difficulties.

$50 \%$ said that the problem forced them to change their research.

$28 \%$ had to abandon their project altogether.

Source $h t t p: / /$ sippi aaas.org/survey
Regulations

on experiments

involving human

subjects are not

always followed to

the letter.

\section{IMAGE \\ UNAVAILABLE FOR COPYRIGHT REASONS}

\title{
Researchers break the rules in frustration at review boards
}

The watchdogs that oversee the ethics of human research projects can sometimes provoke scientific misconduct. That is the counter-intuitive conclusion of a series of papers to be published over the next few months. The authors, who specialize in research ethics, say they have evidence that some ethics panels are alienating researchers and inadvertently promoting deceit.

Patricia Keith-Spiegel of Simmons College in Boston, Massachusetts, says she began her studies after hearing of cases at other US institutions where scientists had violated research rules after feeling that they had been mistreated by institutional review boards (IRBs). Experiments involving human subjects in the United States, from social-science studies to medical research, must be rubber-stamped by an IRB. Researchers acknowledge that the boards are necessary to ensure that subjects are treated correctly, but sometimes complain that the boards fail to understand the research involved and do not explain their decisions properly.

As an example, Keith-Spiegel cites a researcher she knows who became frustrated at lengthy IRB review times and so routinely began data collection before receiving approval. Another researcher admitted to omitting aspects of protocols for research projects after receiving demands for numerous "picky" changes. Typical IRB requests include changes to consent forms or restrictions on the type of questions that subjects can be asked.

"I realized that there are scientists who want to do things the right way but who are having to distort their research protocols because of perceived unreasonable or ridiculous demands from IRBs," says Keith-Spiegel. 